\title{
overall morbidity
}

RRS

ORS

Odds Ratio

Odds Ratio

Study or Subgroup

Events

vents

2011, Bertani

2011, Biffi

2011, deSouza

2011, Park

2013, Kang

2014, Barnajian

2014, Ghezzi

2016, Ozeki

2016, Ramji

2017, Silva-Velazco

2018, Ishihara

Total $(95 \% \mathrm{Cl})$

Total events

Heterogeneity: Chi $^{2}=9.63, d f=10(P=0.47) ; I^{2}=0 \%$

Test for overall effect: $Z=2.74(P=0.006)$
Total

M-H, Fixed, $95 \% \mathrm{Cl}$

M-H, Fixed, $95 \% \mathrm{CI}$

$\begin{array}{rrrrr}18 & 49 & 31 & 105 & 6.8 \% \\ 11 & 36 & 15 & 46 & 5.0 \% \\ 10 & 52 & 18 & 88 & 5.9 \% \\ 34 & 165 & 41 & 165 & 17.9 \% \\ 3 & 20 & 8 & 20 & 3.7 \% \\ 27 & 65 & 45 & 109 & 10.8 \% \\ 7 & 15 & 15 & 22 & 3.6 \% \\ 0 & 26 & 1 & 26 & 0.8 \% \\ 26 & 66 & 168 & 304 & 19.9 \% \\ 22 & 130 & 62 & 234 & 20.2 \%\end{array}$

$0.77[0.30,1.98]$

$1.39[0.68,2.84]$

$0.91[0.36,2.33]$

$0.93[0.39,2.19]$

$0.78[0.47,1.32]$

$0.26[0.06,1.21]$

$1.01[0.54,1.89]$

$0.41[0.11,1.58]$

$0.32[0.01,8.24]$

$0.53[0.31,0.91]$

$0.57[0.33,0.97]$

$1153 \quad 100.0 \%$

$0.73[0.59,0.91]$

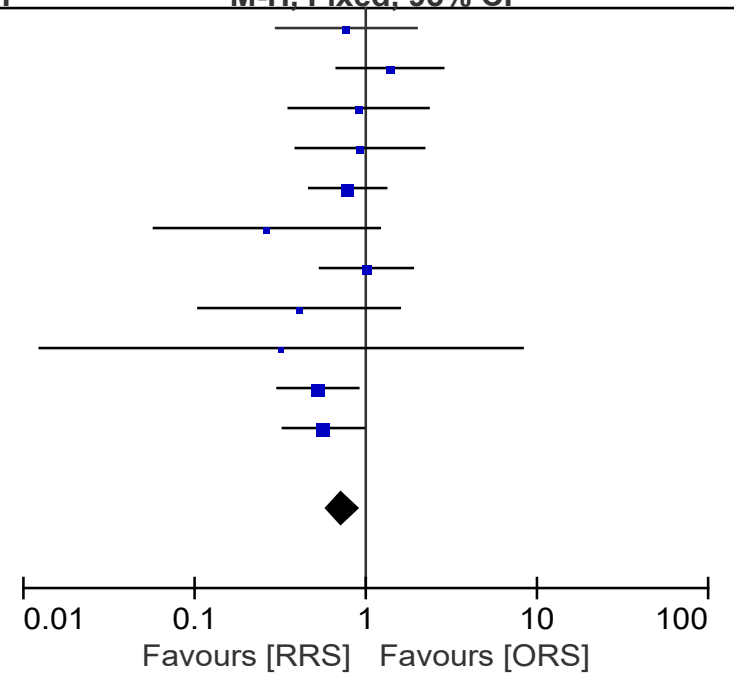

